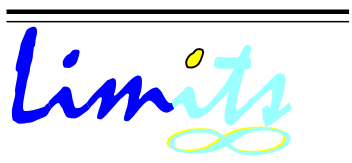

J. Math. and Its Appl.

ISSN : $1829-605 \mathrm{X}$

Vol. 1, No. 2, Nov. 2004, 21-27

\title{
Desain Class Dan Analisis Operator Pada Class Integer Tak Terbatas
}

\author{
Bandung Arry Sanjoyo \\ Jurusan Matematika FMIPA - ITS \\ email:bandung@matematika.its.ac.id
}

\section{Ringkasan}

Pada makalah ini dibahas tentang representasi bilangan bulat (integer) dengan ukuran digit yang sangat besar. Representasi data dan operasi yang terkait diwujudkan dalam bentuk class integer. Struktur data yang digunakan untuk menyimpan bilangan berupa list (array) of character. Sedangkan operator-operator terkait yang bekerja pada integer adalah perbandingan, penjumlahan, pengurangan, perkalian dan pembagian. Analisis operator dibahas secara analitis.

Keyword: Class, integer, worstcase.

\section{Pendahuluan}

Dalam sistem bilangan, bilangan integer (bulat) $0,+1,+2$, banyak dipakai dalam berbagai bidang termasuk dalam bidang sain, teknik, social, ataupun humaniora. Implementasi bilangan integer dalam komputer terbatas pada berapa besar bit yang dialokasikan untuk interger tersebut. Berbagai macam bahasa pemrograman yang ada saat ini, seperti Visual $\mathrm{C}++$, Visual Basic, Matlab dan lainnya, memberikan tempat dimemori untuk menyimpan integer sebesar 64bit. Oleh karena itu bilangan integer terbesar yang dapat disimpan tidak dapat melebihi $2^{63}-1$, untuk di Matlab maksimal $2^{53}-1$ atau kalau dalam digit decimal tidak lebih dari 16 digit [3]. 
Permasalahan sekuritas data (encryption, decryption) akan melibatkan bilangan prima (bagian dari integer) dengan jumlah digit yang sangat besar. Semakin besar bilangan prima yang dipilih, keamanan datanya lebih terjamin. Kerterlibatan integer ini selalu diikuti dengan kebutuhan akan operator seperti penjumlahan, pengurangan, perkalian, dan pembagian, atau bahkan lebih dari operator yang disebutkan tadi. Oleh karena itu, dalam makalah ini akan disajikan bagaimana merepresentasikan integer yang sangat besar (tak terbatas) dan bagaimana mendefinisikan proses operasi pada interger tersebut.

\section{Representasi Integer}

Himpunan $\cdots,-2,-1,0,1,2,3, \cdots$ merupakan himpunan bulangan bulat (integer) dan biasa dinotasikan dengan Z. Sehingga nilai integer bisa mendekati tak berhingga atau banyaknya digit pada integer tersebut sangat besar. Dalam representasi di memori komputer, integer dialokasikan dalam berbagai kapasitas tempat memori (1 byte hingga 8 byte). Integer 2 byte disimpan dalam format sebagai berikut[3].

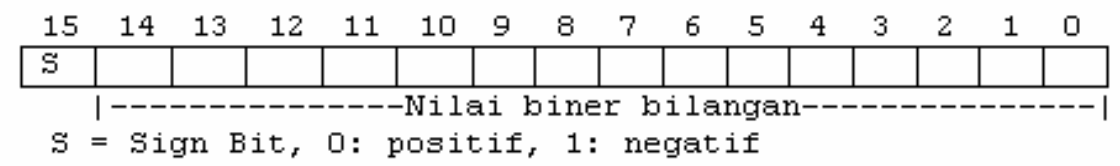

Bilangan terkecil dan terbesar yang dapat disimpan dalam integer 2 byte adalah -32,768 sampai dengan 32,767. Untuk kapasitas integer 64 bit atau 8 byte, nilai integer dapat ditampung adalah 9,223,372,036,854,775,808 sampai dengan $9,223,372,036,854,775,807$. Oleh karena itu untuk integer yang lebih dari 19 digit (integer tak terbatas) tidak mampu ditampung. Penyimpanan integer tak terbatas disimpan dalam bentuk sederetan karakter yang dinamis atau array of character.

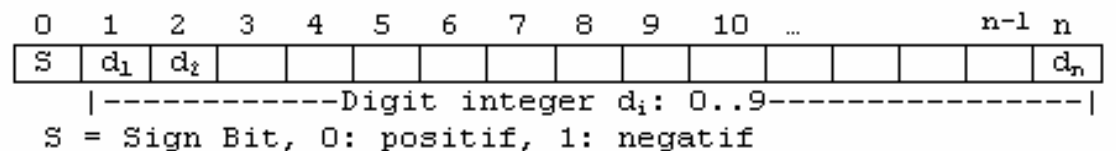

Bentuk representasi di atas dapat dinyatakan dalam bentuk struktur data berikut ini.

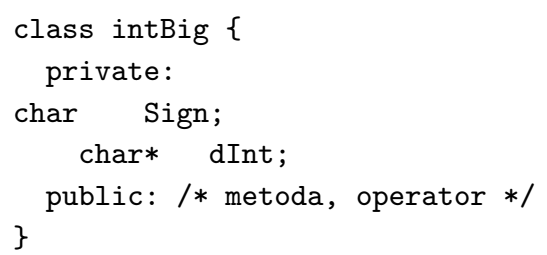

Integer $\mathrm{i}=-111112222233333444445555566666777778888899999$ direpresentasikan 
dalam bentuk berikut ini.

Sim.

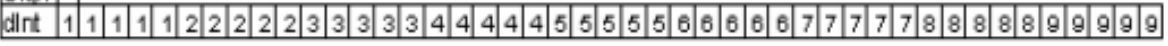

Dengan struktur data seperti di atas, integer dengan banyak digit sembarang akan bias ditampung. Namun demikian terbatas juga pada besarnya free memory yang tersedia.

\section{Pembentukan Class Integer Tak Terbatas}

Suatu hal yang mendasar dalam desain class adalah identifikasi objek (benda) dan kerja/operasi yang bekerja pada objek tersebut. Pada integer dikenali:

i. Objek: tanda bilangan (+/-) atau disimbolkan dengan Sign, dan

ii. Operasi:
(a) Pendefinisian objek atau constructor.
(b) Operasi perbandingan: untuk membandingkan dua integer besar.
(c) Operasi penjumlahan: untuk menjumlahkan dua buah integer besar.
(d) Operasi pengurangan: untuk mengurangkan dua buah integer besar.
(e) Operasi perkalian: untuk mengalikan dua buah integer besar.
(f) Operasi pembagian: untuk membagi dua buah integer besar.
(g) Operasi menampilkan integer besar.

Operasi yang selain disebutkan di atas belum dibahas dalam penelitian ini. Identifikasi di atas dapat dinyatakan dalam suatu bentuk desain class integer besar (intBig) sebagai berikut.

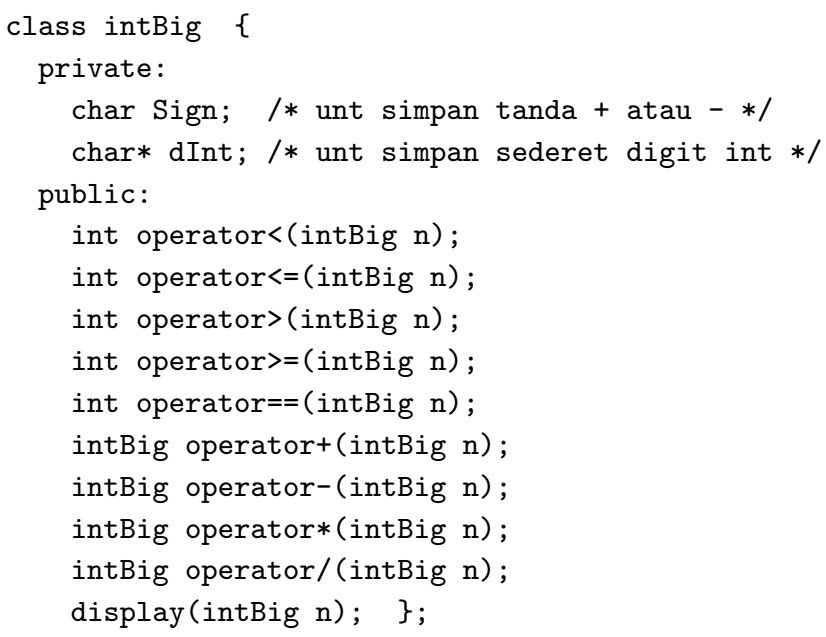




\section{Desain Dan Analisis Algoritma Untuk Operator Pada Class Integer Tak Terbatas}

Strategi atau metoda dari operasi perbandingan, pengurangan dan penjumlahan dapat dilihat pada Bandung A.S. [1]. Dalam penelitian ini akan dibuat algoritma untuk perkalian dan pembagian. Algoritma Perkalian Ada beberapa cara mengalikan dua buah integer, diantaranya adalah penjumlahan berulang dan metoda geser kiri.

Penjumlahan berulang Perkalian dua integer $a \times b$, dapat dilakukan dengan cara sebagai berikut. $a \times b=b+b+\ldots+b$, penjumlahan $b$ dengan $b$ dikumulasikan sebanyak $a$ kali. Strategi demikian dapat diimplementasikan sebagai berikut.

Input : integer besar a dan b.

Output : integer besar r.

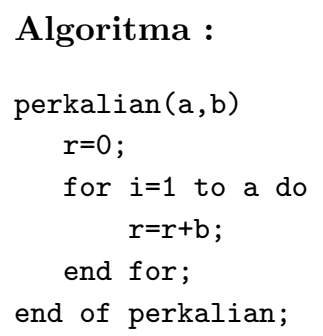

Dalam worst case, algoritma diatas bekerja sebanyak $a$ buah penjumlahan integer besar. Untuk kasus dimana nilai $a$ jauh lebih besar dari pada panjang $s$, dilakukan perbaikan algoritma sebagai berikut.

Metoda Geser Kiri ini sudah dikenal sejak sekolah dasar, dan digambar dengan contoh berikut ini. $321 * 1234$ dilakukan dengan cara:

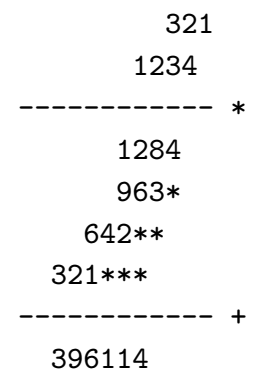

Pada contoh diatas $a * b$, integer yang dikalikan $a=321$ dan pengali $b=$ 1234. Integer $a$ dikalikan dengan setiap digit pada integer $b$, dari digit paling kanan ke kiri. Pada setiap perkalian dilakukan pergeseran satu digit ke kiri. Dan 
selanjutnya dilakukan penjumlahan terhadap hasil perkalian dari setiap digit $n$. Strategi perkalian di atas dapat dikodekan sebagai berikut.

Input : integer besar $a$ dan $b$, dengan $m=|a|$ dan $n=|b|$

Output : integer besar $r$.

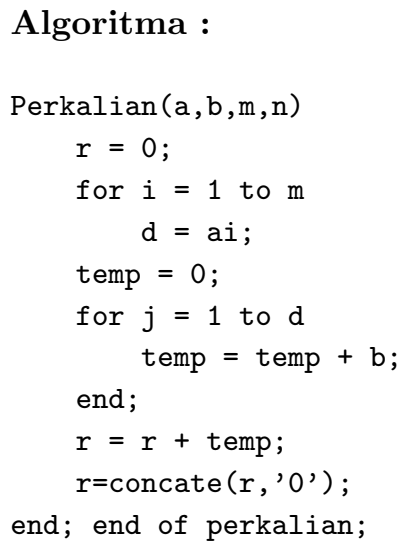

Dalam worst case, algoritma diatas bekerja $10 \mathrm{~m}$ buah operasi jumlah dan concate. Untuk kasus dimana nilai $m<n$ akan bekerja lebih cepat dari pada $m>n$.

Algoritma Pembagian Metoda Pengurangan Berulang Pembagian dua integer $a / b$, dapat dilakukan dengan cara sebagai berikut: $a / b=a-b-b-\ldots-b$, pengurangan $a$ dengan $b$ sebanyak $n$ kali, $n$ adalah hasil pembagian. Strategi demikian dapat diimplementasikan sebagai berikut.

Input : integer besar $s$ dan $d$, dengan $s>d>0$

Output : integer besar $m$.

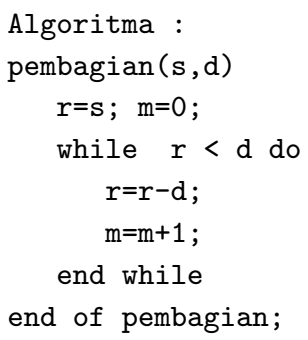

Dalam worst case, algoritma diatas bekerja $s / d$. Untuk kasus dimana nilai $s / d$ jauh lebih besar dari pada panjang $s$, dilakukan perbaikan algoritma sebagai berikut. 
Metoda Paragapit Cara pembagian paragapit $s / d$ digambarkan dengan contoh berikut ini.

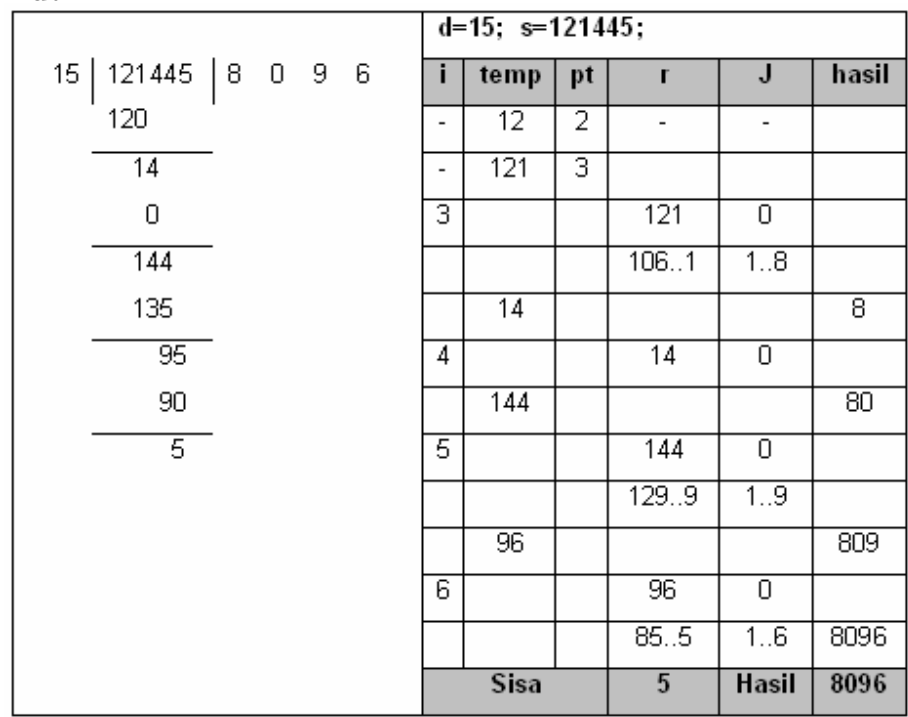

Strategi pembagian di atas dikodekan sebagai berikut.

Input : integer besar $s$ dan $d$, dengan $s>d>0, m=|s|$ dan $n=|d|$

Output : integer besar hasil

\section{Algoritma :}

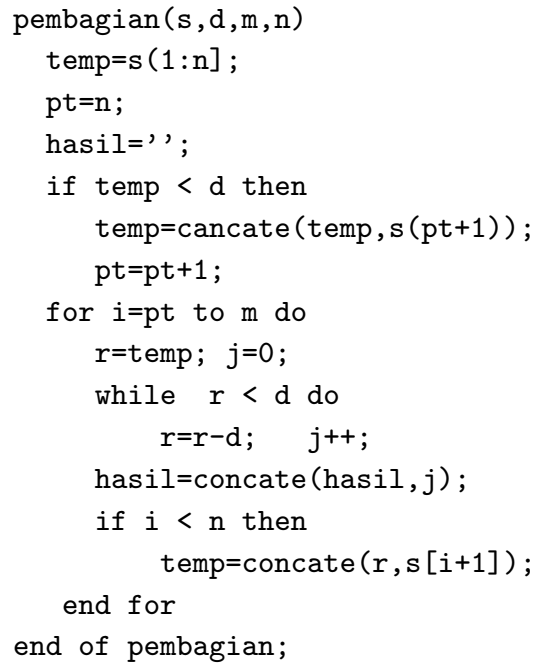

Dalam worst case, algoritma diatas bekerja kurang dari $m n-n^{2}+n=\mathcal{O}(m n)$. 


\section{Kesimpulan}

(a) Integer yang dinyatakan dalam class berbentuk sederetan karakter 0-9 memungkinkan untuk menyimpan integer dengan panjang digit tak terbatas sesuai kemampuan memori computer.

(b) Operator perkalian integer dengan integer dapat dilakukan dengan kecepatan proses $10 \times$ banyaknya digit pada integer yang dioperasikan.

(c) Operator pembagian integer dengan integer dapat dilakukan dengan kecepatan proses tidak lebih dari $m n-n^{2}+n$.

\section{Pustaka}

[1] Bandung Arry S, 2004, Handout Kuliah Matematika Komputasi, Pasca Sarjana Program Studi Matematika.

[2] Kamin, 1996, S.N. dan Reinghold, E.M., Programming With Class - A C++ Introduction to Computer Science, The McGraw-Hill Companies, Inc., International Edition.

[3] Brian Brown, 1984-2000, Data Structures And Number Systems, http://www.ibilce.unesp.br.

[4] 2001-2003, The Long Division Algorithm, http://www.mathpath.org/Algor. 